\title{
A decade of G3P[8] and G9P[8] rotaviruses in Brazil: Epidemiology and evolutionary analyses
}

\author{
Mariela Martínez Gómez ${ }^{\mathrm{a}, *, 1}$, Filipe Anibal Carvalho-Costa ${ }^{\mathrm{a}, 1}$, Eduardo de Mello Volotão ${ }^{\mathrm{a}}$, \\ Tatiana Lundgren Rose ${ }^{a}$, Marcelle Figueira Marques da Silva ${ }^{a}$, Alexandre Madi Fialho ${ }^{a}$, \\ Rosane Maria Santos de Assis ${ }^{a}$, Jelle Matthijnssens ${ }^{b}$, José Paulo Gagliardi Leite ${ }^{a}$ \\ ${ }^{a}$ Laboratory of Comparative and Environmental Virology, Oswaldo Cruz Institute-Fiocruz, Rio de Janeiro, RJ, Brazil \\ ${ }^{\mathrm{b}}$ Laboratory of Clinical and Epidemiological Virology, Department of Microbiology and Immunology, Rega Institute for Medical Research, University of Leuven, Leuven, Belgium
}

\section{A R T I C L E I N F O}

\section{Article history:}

Received 4 March 2014

Received in revised form 9 May 2014

Accepted 14 May 2014

Available online 23 May 2014

\section{Keywords:}

Diarrheal disease

Group A rotaviruses

Genotypes G3 and G9

Phylogenetic analysis

Monovalent vaccine

\begin{abstract}
A B S T R A C T
This study aims to estimate the frequency of group A rotaviruses (RVA) infection with genotypes G3P[8] and G9P[8] in children that suffered from diarrheal disease (DD) between 2001 and 2011 in different Brazilian regions. In addition, the genetic diversity of G3P[8] and G9P[8] RVA strains recovered from vaccinated and non-vaccinated children was assessed. Laboratory-based RVA surveillance included 15,115 cases of DD, and RVA was detected by enzyme immune-assay and/or polyacrylamide gel electrophoresis in 3357 (22\%) samples. RVA was genotyped by the semi-nested RT-PCR and among RVA-positive samples, $100(2.9 \%)$ were G3 (63 G3P[8], 32 G3P not typed [NT], and 5 G3P[6]) and 378 (16.2\%) were G9 (318 G9P[8], 59 G9P[NT], and 1 G9P[6]). From the G3 and G9 positive samples, 16 and 12, respectively, were obtained from children aged 4-48 months vaccinated with the monovalent vaccine (Rotarix ${ }^{\circledR}, \mathrm{RV} 1$ ). Phylogenetic analyses of the VP7 and VP8* encoding genes were performed for 26 G3P[8] and 48 G9P[8] strains. VP8* phylogenetic analysis revealed that all strains analyzed belonged to P[8] lineage III, whereas RV1 belongs to P[8]-I lineage. VP7 analysis revealed that all G3 and G9 strains belonged to G3-lineage III and G9-lineage III. The comparison of the VP7 and VP8* antigenic epitopes regions of Brazilian strains with RV1 strain revealed several amino acid changes. However, no particular differences among Brazilian strains detected before and after vaccine introduction were observed, or among strains detected from vaccinated and non-vaccinated children. Complete genome characterization of four G3P[8] and seven G9P[8] strains revealed a typical conserved human Wa-like genomic constellation. Changes in the genetic diversity of G3P[8] and G9P[8] RVA detected from 2001 to 2011 in Brazil seemed not be related to RV1 introduction in Brazil.
\end{abstract}

(c) 2014 Elsevier B.V. All rights reserved.

\section{Introduction}

Despite the continuing reduction on the burden of diarrheal disease (DD) in recent years, DD still represents the second leading cause of death in children $\leqslant 5$ years old in the developing world (Black et al., 2010; Wazny et al., 2013). Group A rotaviruses (RVA) are the main etiologic agent of DD in children in this age group worldwide, with a high mortality impact in Africa and Asia (Kotloff et al., 2013). According to the estimates for 2008, RVA were

\footnotetext{
* Corresponding author. Address: Laboratório de Virologia Comparada e Ambiental, Instituto Oswaldo Cruz, Av. Brazil, 4365 - Pavilhão Hélio \& Peggy Pereira, 21040-360 Rio de Janeiro, RJ, Brazil. Tel.: +55 21 981910606; fax: + 552125621851

E-mail addresses: marielamartinezgomez@gmail.com, marie@ioc.fiocruz.br (M. M. Gómez).

1 These authors contributed equally for the manuscript.
}

associated with 453,000 deaths worldwide among children $\leqslant 5$ years old, mainly $(>80 \%)$ in countries in Asia and Sub-Saharan Africa (Tate et al., 2012). RVA mortality have been estimated to 196,000 cases/year in 2011 (Walker et al., 2013).

RVA belongs to the Reoviridae family, possessing a genome of 11 double-stranded RNA gene segments encoding six structural (VP1VP4, VP6-VP7) and six non-structural proteins (NSP1-NSP6). A binary classification system was established for RVA based on the two gene segments encoding the outer capsid proteins, VP4 (P-genotype) and VP7 (G-genotype) (Estes and Greenberg, 2013). More recently, an extended classification system has been proposed including all 11 gene segments and, to date, containing 27 G, 37 P, 16 I, 9 R, 9 C, 8 M, 16 A, 9 N, 12 T, 14 E and 11 H genotypes, respectively (Matthijnssens et al., 2008; Trojnar et al., 2013).

Epidemiological studies of RVA infections have demonstrated a significant genetic diversity of strains co-circulating in different 
continents. In humans, at least six RVA G genotypes (G1-G4, G9, and more recently G12), and three P genotypes (P[8], P[4], and more recently $\mathrm{P}[6])$ circulates worldwide generating a major impact in public health (Leite et al., 2008; Iturriza-Gómara et al., 2009; Bányai et al., 2012). The spread of different RVA genotypes and the emergence of novel genetic variants in distinct geographical regions and at different points in time, are likely to influence severe DD (Carvalho-Costa et al., 2011; WHO, 2013).

RVA genotype G9 emerged during the 1990s and reports demonstrated its importance in the burden of DD on a global scale (Laird et al., 2003; Gentsch et al., 2005; Rahman et al., 2005, 2008; Carvalho-Costa et al., 2006; Endara et al., 2007; Matthijnssens et al., 2010a). This genotype has been detected possessing a Walike or DS-1-like genomic constellation or a combination of both (Page et al., 2010; Matthijnssens \& Van Ranst, 2012).

Among RVA genotypes described so far, genotype G3 has the largest host range, being described in different species as: monkeys, rabbits, pigs, poultry, dogs, cats, horses, mice, sheep, humans, etc. (De Grazia et al., 2010; Matthijnssens et al., 2010b; Guo et al., 2012; Malik et al., 2012; Nemoto et al., 2012; He et al., 2013; Okitsu et al., 2013). An overall increase in the prevalence of G3 strains has been recently reported in many countries, some of them in association with the introduction of the pentavalent RVA vaccine (RotaTeq ${ }^{\circledR}$, RV5) (Ngo et al., 2009; Hull et al., 2011; Kirkwood et al., 2011; Mitui et al., 2011).

The binary combinations G3P[8] and G9P[8] are among the most frequently observed in humans worldwide (SánchezFauquier et al., 2006; Leite et al., 2008; Carvalho-Costa et al., 2011; Esona et al., 2013). A high genetic heterogeneity was observed for these genotypes, generated by point mutations in the VP7 encoding gene. Nucleotide sequence analyses indicate the presence of several genetically distinct, co-circulating clades of G3P[8] and G9P[8] viruses, which contained minor but significant differences in their encoded proteins (McDonald et al., 2009a,b; Esona et al., 2013; Nyaga et al., 2013).

Brazil introduced universal vaccination with the monovalent G1P[8] RVA vaccine (Rotarix ${ }^{\circledR}$, RV1) in March, 2006. After mass vaccination, the RVA epidemiology changed, and genotype G2P[4] became the most prevalent genotype detected in Brazil. In addition, differences in the G3P[8] and G9P[8] prevalence have been observed in different Brazilian regions (Leite et al., 2008; Carvalho-Costa et al., 2009, 2011; Linhares et al., 2011; Linhares and Justino, 2014). In this report, phylogenetic analysis and epidemiological aspects of RVA genotypes G3P[8] and G9P[8] strains are described, including those obtained from vaccinated children. In addition, the complete genetic constellation of all 11 gene segments was determined for four G3P[8] and seven G9P[8] Brazilian strains to further explore the genetic variability of these strains and compared with RV1 and contemporary RVA strains.

\section{Material and methods}

\subsection{Laboratory-based group A rotaviruses surveillance}

RVA surveillance was performed between January 2001 and December 2011 in 23 Brazilian states. A total of 15,115 fecal samples from DD cases were studied. RVA surveillance is performed through a hierarchical network in which samples are provided by medical request in hospitals and health centers, monitored by the Brazilian Unified Health System (SUS). The fecal samples were collected by the Central Laboratory of each state and then forwarded to the Regional Rotavirus Reference Laboratory - Laboratory of Comparative and Environmental Virology, Oswaldo Cruz Institute, Fiocruz. Forms with epidemiological, clinical, and RVA vaccination data (after March 2006) accompanied each fecal sam- ple. This study is part of a project that covers diagnosis, surveillance and molecular epidemiology of viruses that cause DD approved by the Ethics Committee of Fiocruz (CEP: 311/06).

\subsection{Group A rotavirus detection and G- and P-genotyping}

RVA detection in fecal samples was carried out by enzyme immunoassay (EIA, Premier Rotaclone ${ }^{\circledR}$, Meridian Bioscience, Inc.; Ridascreen ${ }^{\circledR}$, R-Biopharm) and polyacrylamide gel electrophoresis (PAGE) (Pereira et al., 1983). Nucleic acids were extracted from $10 \%$ fecal suspensions by the glass powder method described by Boom et al. (1990), including modifications (Leite et al., 1996) or the QIAamp Viral RNA mini kit (Qiagen ${ }^{\circledR} /$ Westburg, Leusden, The Netherlands) according to the manufacturer's instructions. The extracted RNA was reverse transcribed and RVA G- and P- genotyping was performed using semi-nested multiplex PCRs as previously described (WHO/IVB/08.17, 2008).

\subsection{VP7 and VP8* sequencing and phylogenetic analysis}

Twenty-six G3 (21 from the post vaccination period, including nine from vaccinated children) and 48 G9 (9 from the post vaccination period, including two from vaccinated children) positive samples recovered between 2001 and 2011 were selected for VP7 and VP8* sequence analyses, respectively. Criteria used to select the samples were: number of positive samples per year (vaccinated and non-vaccinated), amount of fecal sample, and quality of extracted RNA. The cDNA products were resolved on agarose gels electrophoresis and purified using the Expo-SAP-IT PCR Product Cleanup Kit (Affymetrix, Miles Rd, Cleveland, OH, USA). Sequencing was performed with an ABI Prism Big Dye Terminator Cycle Sequencing Ready Reaction Kit on an ABI Prism 3730 Genetic Analyzer (Applied Biosystems ${ }^{\circledR}$, Foster City, CA, USA) at the Institute of Technology in Immunobiologicals (Bio-Manguinhos, Fiocruz), or an ABI Prism 3130 automated sequencer (Applied Biosystems ${ }^{\circledR}$, Foster City, CA, USA) at the Rega Institute of Medical Research (University of Leuven, Belgium). Nucleotide BLAST analyses were performed and multiple sequence alignments were carried out using the ClustalW program (Thompson et al., 1994). Phylogenetic analyses were constructed using the Neighbor-Joining method with the Kimura-two parameter model in MEGA5.0 (Tamura et al., 2011). The statistical significance of the nodes was assessed by bootstrap resampling analysis (2000 replicates). Deduced amino acid sequences of VP8* and VP7 proteins of Brazilian G3P[8] and G9P[8] RVA strains were compared with the RV1 strain using the Bioedit v.7.2.3 software (Hall, 1999). Sequences obtained in the current study were deposited in the GenBank database under the following accession numbers: VP7: KJ454448 - KJ454518; VP8*: KJ454519 - KJ454592.

\subsection{Eleven genes amplification and sequencing}

The amplification of the eleven genome segments from four G3P[8] and seven G9P[8] strains were performed using a OneStep RT-PCR Kit $\left(\right.$ QIAGEN $\left.^{\circledR}\right)$ following the manufacturer's instructions and amplifications conditions as previously described (Tort et al. 2010; da Silva et al., 2011; Gómez et al., 2013; Rose et al., 2013). Purification and sequencing conditions are the same as previously described for VP7 and VP8* encoding genes. Accession numbers corresponding to obtained sequences are: VP6: KJ454593 - KJ454601; VP1: KJ454602 - KJ454610; VP2: KJ454611 - KJ454620; VP3: KJ454621 - KJ454624; NSP1: KJ454625 - KJ454633; NSP2: KJ454634 - KJ454644; NSP3: KJ454645 - KJ454653; NSP4: KJ454654 - KJ454664; NSP5: KJ454665 - KJ454673. 


\section{Results}

\subsection{Laboratory-based group A rotaviruses surveillance}

From 2001 to 2011, fecal samples obtained from patients with DD were analyzed and 3357 out of 15,115 (22\%) were positive for RVA. Globally, among these 3357 RVA-positive samples, 100 (2.9\%) were G3 (63 G3P[8], 32 G3P not typed [NT], and 5 G3P[6]) and 378 (16.2\%) were G9 (318 G9P[8], 59 G9P[NT], and 1 G9P[6]).

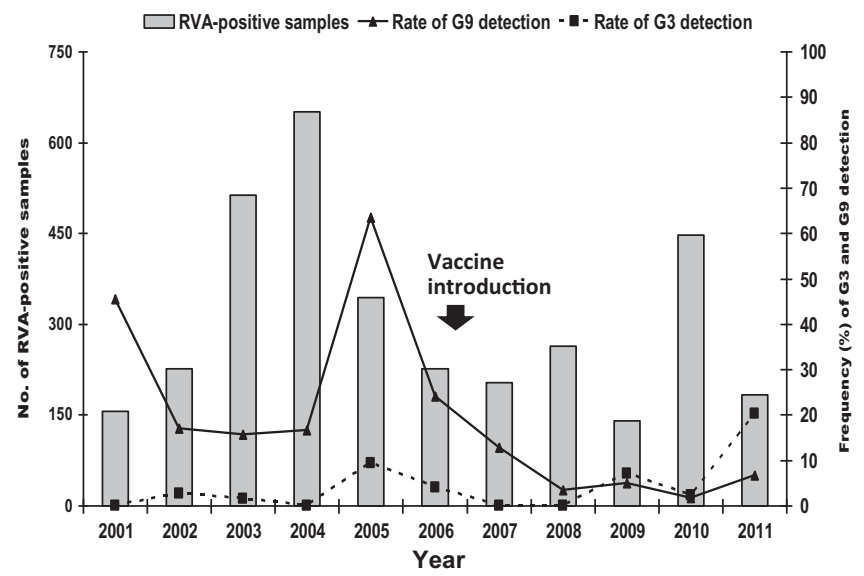

Fig. 1. Rates of G3 and G9 group A rotavirus (RVA) genotypes detection in positive fecal samples though laboratory-based surveillance.
Prior to RV1 introduction, from 2001 to 2005, including a large RVA outbreak occurred in the state of Acre in 2005, the overall RVA detection rate was $1892 / 7334$ (25.8\%); the frequency of G3 and G9 identification in RVA-positive samples was 36 (1.9\%) and 304 (16.1\%), respectively. In the post vaccination era, 7781 samples were studied, 1465 (18.8\%) were positive for RVA, including 66 (4.5\%) G3 and 114 (7.8\%) G9 strains. Fig. 1 presents the global rate of G3 and G9 detection by year, from 2001 to 2011.

Concerning children aged 4-48 months, 3531 samples were studied in the pre vaccination period, 1065 (30\%) being RVA-positive. Frequency of G3 and G9 detection was 33 (3.1\%) and 212 (19.9\%), respectively. In the post vaccination period (from 2006 on), 1601 studied samples were from children aged 4-48 months vaccinated with two doses of RV1. The frequency of RVA detection among these vaccinated children was 293/1601 (18.3\%). Among non-vaccinated children in the same age group, the RVA detection rate was 160/543 (29.5\%), $p<0.001$ (chi-square test).

Table 1 summarizes the results of RVA detection as well as epidemiological information about G3 and G9 infections. The rate of detection of G3 among RVA-positive vaccinated (16/293 [5.4\%]) and RVA-positive unvaccinated (12/160 [7.5\%]) children was simi$\operatorname{lar}(p=0.808$; Yates corrected chi-square test). Frequency of detection of G9 was also similar among vaccinated (12/293 [4.1\%]) and unvaccinated (8/160 [5\%]) RVA-positive children $(p=0.828$; Yates corrected chi-square test).

\subsection{VP7 and VP8* sequence and phylogenetic analysis}

A total of 74 VP7 and VP8* nucleotide sequences were analyzed from strains detected from 2001 to 2011 (26 G3P[8] and 48

Table 1

Year distribution of group-A rotavirus (RVA) infections and rate of detection of G3 and G9 genotypes in vaccinated and unvaccinated children aged 4-48 months.

\begin{tabular}{|c|c|c|c|c|c|c|c|}
\hline Year & $\begin{array}{l}\text { Overall year } \\
\text { rate of RVA } \\
\text { detection }\end{array}$ & $\begin{array}{l}\text { Rate of RVA } \\
\text { detection in } \\
\text { unvaccinated } \\
\text { children }\end{array}$ & $\begin{array}{l}\text { Rate of RVA detection } \\
\text { in } \\
\text { vaccinated }^{* * *} \text { children }\end{array}$ & $\begin{array}{l}\text { Rate of G3P[8] or } \\
\text { G3P[NT] }]^{\S} \text { detection in } \\
\text { RVA-positive } \\
\text { unvaccinated children }\end{array}$ & $\begin{array}{l}\text { Rate of G3P[8] or } \\
\text { G3P[NT] detection in } \\
\text { RVA-positive } \\
\text { vaccinated children }\end{array}$ & $\begin{array}{l}\text { Rate of G9P[8] or } \\
\text { G9P[NT] detection in } \\
\text { RVA-positive } \\
\text { unvaccinated children }\end{array}$ & $\begin{array}{l}\text { Rate of G9P[8] or } \\
\text { G9P[NT] detection in } \\
\text { RVA-positive } \\
\text { vaccinated children }\end{array}$ \\
\hline 2001 & $\begin{array}{l}157 / 801 \\
(19.6)\end{array}$ & $\mathrm{NA}^{\ddagger}$ & NA & NA & NA & NA & NA \\
\hline 2002 & $\begin{array}{l}226 / 840 \\
(26.9)\end{array}$ & NA & NA & NA & NA & NA & NA \\
\hline 2003 & $\begin{array}{l}514 / 1856 \\
(27.7)\end{array}$ & NA & NA & NA & NA & NA & NA \\
\hline 2004 & $\begin{array}{l}651 / 2545 \\
(25.6)\end{array}$ & NA & NA & NA & NA & NA & NA \\
\hline 2005 & $\begin{array}{l}344 / 1292 \\
(26.6)\end{array}$ & NA & NA & NA & NA & NA & NA \\
\hline 2006 & $\begin{array}{l}227 / 1576 \\
(14.4)\end{array}$ & $3 / 11(27.3)$ & $0 / 10(0)$ & $0 / 3(0)$ & 0 & $2 / 3(66.7)$ & - \\
\hline 2007 & $\begin{array}{l}203 / 1232 \\
(16.5)\end{array}$ & $35 / 152(23)$ & $13 / 105$ (12.4) & $0 / 35(0)$ & $0 / 13(0)$ & $1 / 35(2.9)$ & $0 / 13(0)$ \\
\hline 2008 & $\begin{array}{l}264 / 1013 \\
(26.1)\end{array}$ & $43 / 117(36.8)$ & $34 / 159(21.4)$ & $0 / 43(0)$ & $0 / 34(0)$ & $3 / 43(7)$ & $3 / 34(8.8)$ \\
\hline 2009 & $\begin{array}{l}141 / 980 \\
(14.4)\end{array}$ & $12 / 89$ (13.5) & $41 / 310(13.5)$ & $1 / 12(8.3)$ & $3 / 41(7.3)$ & $0 / 12(0)$ & $2 / 41(4.9)$ \\
\hline 2010 & $447 / 1863$ (24) & 36/98 (36.7) & $154 / 624$ (24.7) & $1 / 36(2.8)$ & $5 / 154(3.2)$ & $0 / 36(0)$ & $2 / 154(1.2)$ \\
\hline 2011 & $\begin{array}{l}183 / 1117 \\
(16.4)\end{array}$ & $31 / 76(40.8)$ & $51 / 393(13)$ & $10 / 31(32.3)$ & $8 / 51(15.7)$ & $2 / 31(6.4)$ & $5 / 51(9.8)$ \\
\hline Total & $\begin{array}{l}3357 / 15115 \\
(22.2)\end{array}$ & $160 / 543(29.5)^{\dagger}$ & $293 / 1601(18.4)^{\dagger}$ & $12 / 160(7.5)^{\dagger \dagger}$ & $16 / 293(5.5)^{\dagger \dagger}$ & $8 / 160(5)^{\dagger+\dagger}$ & $12 / 293(4.1)^{\dagger+\dagger}$ \\
\hline
\end{tabular}

\footnotetext{
${ }^{*}$ Results are expressed as number of positive subjects/number of tested subjects (\% of positive subjects).

** children aged 4-48 months who did not received two doses of the monovalent vaccine.

**** children aged 4-48 months who received two doses of the monovalent vaccine.

$\S$ Not typed.

\$ Not applicable.

$\dagger p<0.001$.

†े $p=0.808$.

†⿰讠十 $p=0.828$.
} 
G9P[8]). Eleven strains were detected from children vaccinated with RV1: 9 G3P[8], and 2 G9P[8].

Phylogenetic analyses based on the VP8* encoding gene showed that all Brazilian strains grouped inside P[8] lineage-III, in four distinct clusters: (i) G9 strains detected in Acre state in 2005 and previous reported strains in 2006 in Acre by Tort et al. (2010), strains RVA/Human-wt/BRA/ba4931-01/2001/G9P[8] and RVA/Humanwt/BRA/RJ8631/2004/G9P[8] grouped closely to this cluster; (ii) G3 strains detected in 2005-2006, G9 strains detected in 20042007 and RVA/Human-wt/BRA/BA17313/2009/G9P[8]; (iii) G9P[8] strains detected in 2010-2011 (vaccinated and non-vaccinated); (iv) G3P[8] strains detected in 2009-2011 (vaccinated and non-vaccinated). Strain RVA/Human-wt/BRA/RO13270/2006/ G9P[8] grouped in a separate branch and showed closest genetic relationship with G1P[8] strains detected in Belgium (20062008), and strain RVA/Human-wt/BRA/RJ8418/2004/G9P[8] also grouped separately and showed closely genetic relationship with a previous GXP[8] strain detected in Brazil in 2002, and G1P[8] strains detected in Australia and Belgium in 2000 and 1999, respectively (Fig. 2). Identity values among Brazilian strains were $95.7-100 \%$ and $96.2-100 \%$, for nucleotide and amino acid, respectively.

Analysis of VP7 encoding gene revealed that all Brazilian G3 strains belonged to lineage III and shared $98.1-100 \%$ of nucleotide identity. Amino acid identity among Brazilian strains was 99$100 \%$. Although strains were very similar among each other, different cluster could be observed: (i) strains detected from 2004 to 2006 grouped together with one strain detected in 2009 (RVA/ Human-wt/BRA/rs16647/2009/G3P[8]) and showed 100\% nucleotide identity with strains detected in Vietnam (2001-2003) and Thailand (2010-2011); (ii) strains detected in 2009; (iii) strain RVA/Human-wt/BRA/SC18448/2010/G3P[8] (vaccinated) cluster in a separate branch showing $100 \%$ identity with G3P[8] strains from Thailand detected in 2010; (iv) and strains detected in 2011 grouped in two separate clusters (both including vaccinated and non-vaccinated children) (Fig. 3).

G9 strains grouped inside lineage III in different clusters: (i) strains detected between 2001 and 2007, being most of the strains detected in 2004 100\% identical to RVA/Human-wt/BEL/B3458/ 2003/G9P[8] strain; (ii) strains detected in Acre state in 2005; (iii) strains detected between 2009 and 2011 (vaccinated and non-vaccinated), these strains grouped closely to Acre strains; (iv) strains detected in Roraima state in 2006 (Fig. 4). Nucleotide and amino acid identity values among Brazilian strains were $97.1-100 \%$, and $96-100 \%$, respectively.

When comparing the VP7 and VP8* antigenic epitope regions of Brazilian strains with RV1 strain, some amino acid differences were observed. For the VP8* protein region, amino acid differences were observed at positions: N113D, S125N, S131R, N135D, S146G, S190N, and N196G for G3/G9 strains; S131G for G9 strains; and at positions N87D, N150T just for G3 strains (Supplementary material Fig. 1). For the VP7 protein, amino acid changes were observed at positions: G96N, E97S, W98G, S123D, V125A, Q146A, N147T, N211D, V212T, D213N, M217E, N221A, and T242N, for G3 strains; and at positions T87A, N94G, G96T, D100N, S123D, V125A, V129I, Q146S, N147T, V212T, D213A/V, M217E, N221S, N238D, and T242N for G9 strains (Supplementary material Fig. 1). No differences among vaccinated children and non-vaccinated children were observed, as well as between pre- and post-vaccine introduction detected strains.

\subsection{Genome constellation}

Analysis of the partial/complete gene segments of four G3P[8] (RVA/Human-wt/BRA/RJ10911/2005/G3P[8]; RVA/Humanwt/BRA/RS16823/2009/G3P[8]; RVA/Human-wt/BRA/RS20345/

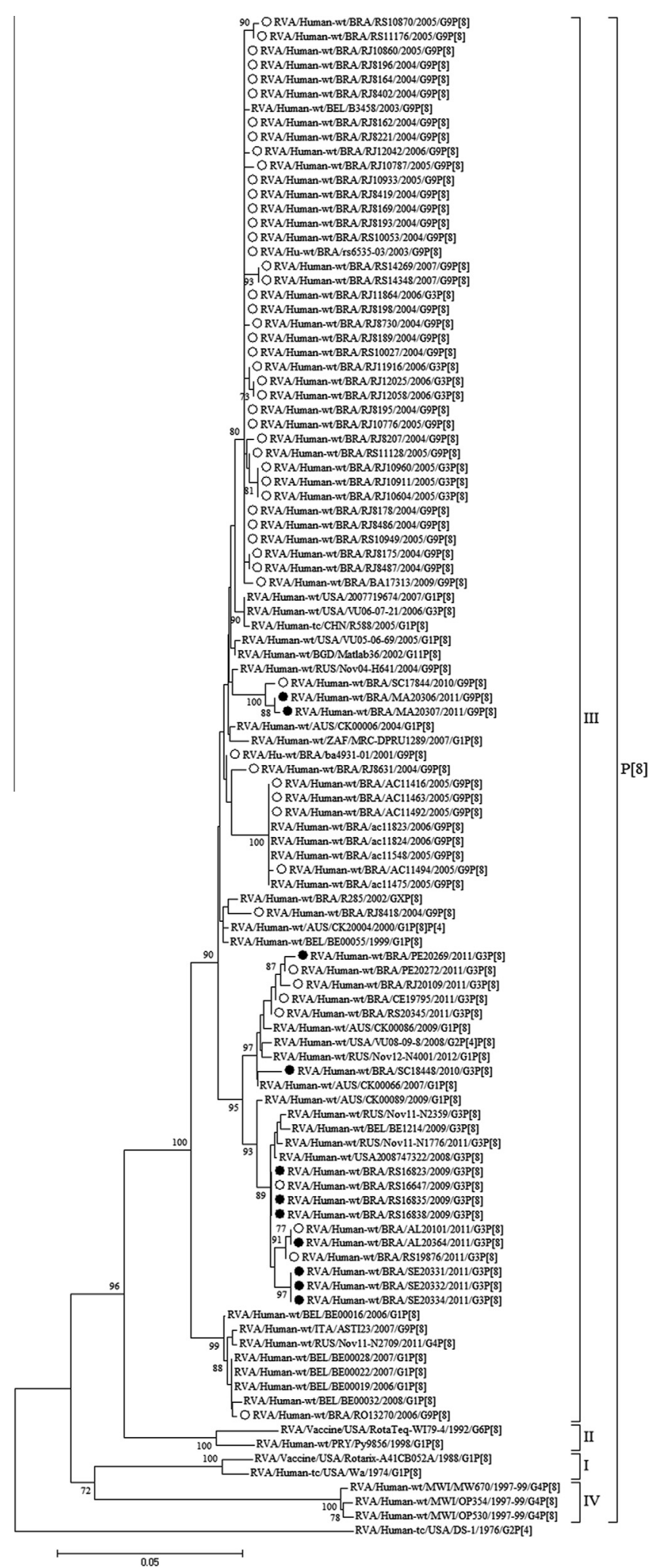

Fig. 2. Phylogenetic analysis based on the VP8* (VP4) gene nucleotide sequences of Brazilian G3P[8] and G9P[8] strains, and sequences from the Genbank database. Brazilian strains obtained from vaccinated and non-vaccinated children are marked with a filled and an empty circle, respectively. Genotype and lineages appeared at the right of the figure. Numbers at the nodes indicate bootstrap values; only values above $70 \%$ are shown. The scale bar at the bottom represents 0.05 substitutions per nucleotide position (nt.subst./site).

2011/G3P[8]; RVA/Human-wt/BRA/SE20323/2011/G3P[8]) and seven G9P[8] (RVA/Human-wt/BRA/ba4931-01/2001/G9P[8]; 
O RVA/Human-wt/BRA/CE19795/2011/G3P[8]

93 O RVA/Human-wt/BRA/RS20345/2011/G3P[8]

RVA/Human-wt/BRA/RJ20109/2011/G3P[8]

O RVA/Human-wt/BRA/PE20272/2011/G3P[8]

RVA/Human-wt/BRA/PE20269/2011/G3P[8]

RVA/Human-wt/ESP/G3-SP5.8-3/2004-6/G3P[X]

RVA/Human-wt/ESP/G3-SP5.7-3/2004-6/G3P[X]

RVA/Human-wt/ESP/G3-SP2.8-3/2004-6/G3P[X]

RVA/Human-wt/CHN/E579/2007/G3P[X]

RVA/Human-wt/CHN/R1455/2007/G3P[X]

RVA/Human-wt/VIE/VN-467/2001-3/G3P[X]

RVA/Human-wt/VIE/VN-463/2001-3/G3P[X]

RVA/Human-wt/CHN/R709/200X/G3P[X]

RVA/Human-wt/CHN/Z409/2005/G3P[X]

O RVA/Human-wt/BRA/RJ11864/2006/G3P[8]

O RVA/Human-wt/BRA/RJ10908/2005/G3P[8]

O RVA/Human-wt/BRA/rj10658/2005/G3P[8]

O RVA/Human-wt/BRA/RJ12058/2006/G3P[8]

O RVA/Human-wt/BRA/RJ11916/2006/G3P[8]

O RVA/Human-wt/BRA/RJ12025/2006/G3P[8]

O RVA/Human-wt/BRA/RJ10960/2005/G3P[8]

O RVA/Human-wt/BRA/RJ10547/2004/G3P[8]

RVA/Human-wt/THA/CU1023-KK/2011/G3P[X]

RVA/Human-wt/THA/CU778-KK/2010/G3P[X]

O RVA/Human-wt/BRA/RJ10911/2005/G3P[8]

O RVA/Human-wt/BRA/rs16647/2009/G3P[8]

— RVA/Human-wt/USA/VU08-09-30/2008/G3P[8]

RVA/Human-wt/ARG/Arg5812/2007/G3P[8]

RVA/Human-wt/ESP/G3-SP1.9-3/2004-6/G3P[X]

RVA/Human-wt/ARG/Arg6295/2007/G3P[X]

100

RVA/Human-wt/BRA/RS16838/2009/G3P[8]

RVA/Human-wt/BRA/RS16835/2009/G3P[8]

RVA/Human-wt/BRA/RS16823/2009/G3P[8]

O RVA/Human-wt/BRA/RS19876/2011/G3P[8]

O RVA/Human-wt/BRA/AL20101/2011/G3P[8]

RVA/Human-wt/BRA/AL20364/2011/G3P[8]

RVA/Human-wt/BRA/SE20331/2011/G3P[8]

RVA/Human-wt/BRA/SE20332/2011/G3P[8]

RVA/Human-wt/BRA/SE20334/2011/G3P[8]

97 O RVA/Human-wt/BRA/se20323/2011/G3P[8]

RVA/Human-wt/THA/CU747-KK/2010/G3P[8]

RVA/Human-wt/THA/CU766-KK/2010/G3P[8]

RVA/Human-wt/THA/CU822-KK/2010/G3P[X]

95 RVA/Human-wt/THA/CU766-KK/2010/G3P[8]

RVA/Human-wt/BRA/SC18448/2010/G3P[8]

RVA/Cow-tc/GBR/PP-1/1976/G3P[7]

RVA/Pig-wt/SLO/P50/2004-5/G3P[X]

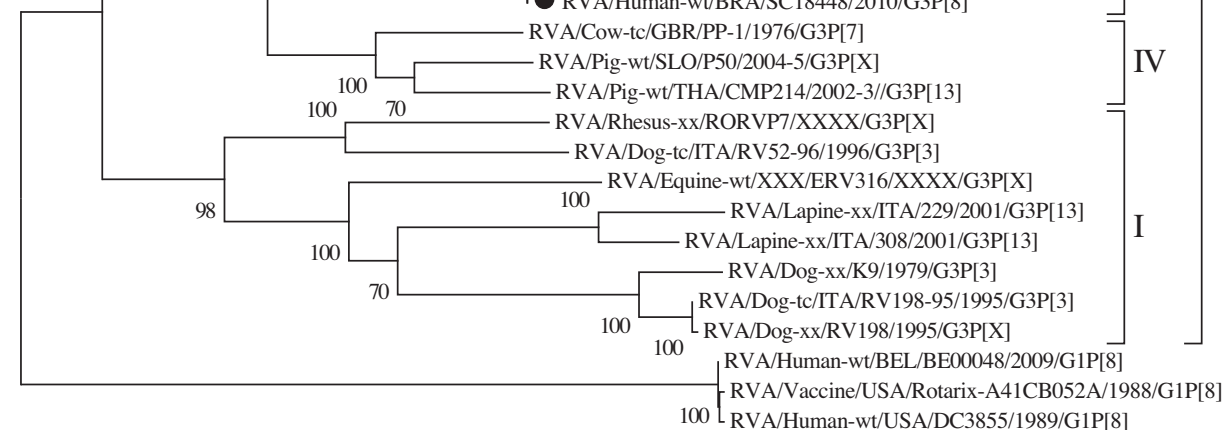

$100\left[\begin{array}{l}\text { RVA/Vaccine/USA/Rotarix-A41CB052A/19 } \\ \text { RVA/Human-wt/USA/DC3855/1989/G1P[8] }\end{array}\right.$

0.05

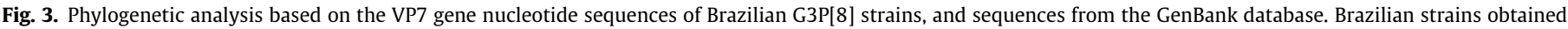

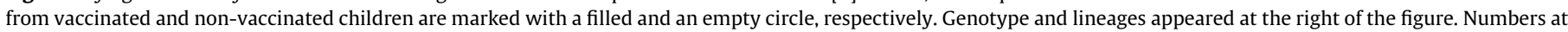
the nodes indicate bootstrap values; only values above $70 \%$ are shown. The scale bar at the bottom represents 0.05 substitutions per nucleotide position (nt.subst./site).

RVA/Human-wt/BRA/rs6535-03/2003/G9P[8]; RVA/Human-wt/ BRA/RJ8224/2004/G9P[8]; RVA/Human-wt/BRA/RJ10650/2005/ G9P[8]; RVA/Human-wt/BRA/RJ10748/2005/G9P[8]; RVA/Humanwt/BRA/AC11824/2006/G9P[8]; RVA/Human-wt/BRA/MA20306/ 2011/G9P[8]) strains revealed the typical Wa-like genome constellations G3-P[8]-I1-R1-C1-M1-A1-N1-T1-E1-H1 and G9-P[8]-I1-R1C1-M1-A1-N1-T1-E1-H1, respectively (Table 2). A total of 101 sequences were obtained, 54 corresponding to complete open reading frame $(\mathrm{ORF})$ gene sequences $(\mathrm{VP7}=7 ; \mathrm{VP} 4=3$; $\mathrm{VP} 6=2$; $\mathrm{VP} 2=1 ; \quad \mathrm{VP} 3=1 ; \quad \mathrm{NSP} 1=5 ; \quad \mathrm{NSP} 2=11 ; \quad \mathrm{NSP} 3=5 ; \quad \mathrm{NSP} 4=10 ;$ NSP5 $=9$ ) and 47 to partial ORF gene sequences $(\mathrm{VP7}=2$;
$\mathrm{VP4}=8 ; \mathrm{VP6}=7 ; \mathrm{VP1}=9 ; \mathrm{VP2}=9 ; \mathrm{VP3}=3 ; \mathrm{NSP} 1=4 ; \mathrm{NSP} 3=4$; NSP4 = 1). Sequences of VP7, NSP1, NSP3 and NSP5 encoding genes of strains RVA/Human-wt/BRA/RJ8224/2004/G9P[8] and RVA/ Human-wt/BRA/AC11824/2006/G9P[8] were reported in a previous study by Tort et al. (2010).

\section{Discussion}

Recent post-licensing studies have demonstrated that RV1 effectiveness ranges from $78 \%$ to $91 \%$ in the United States 


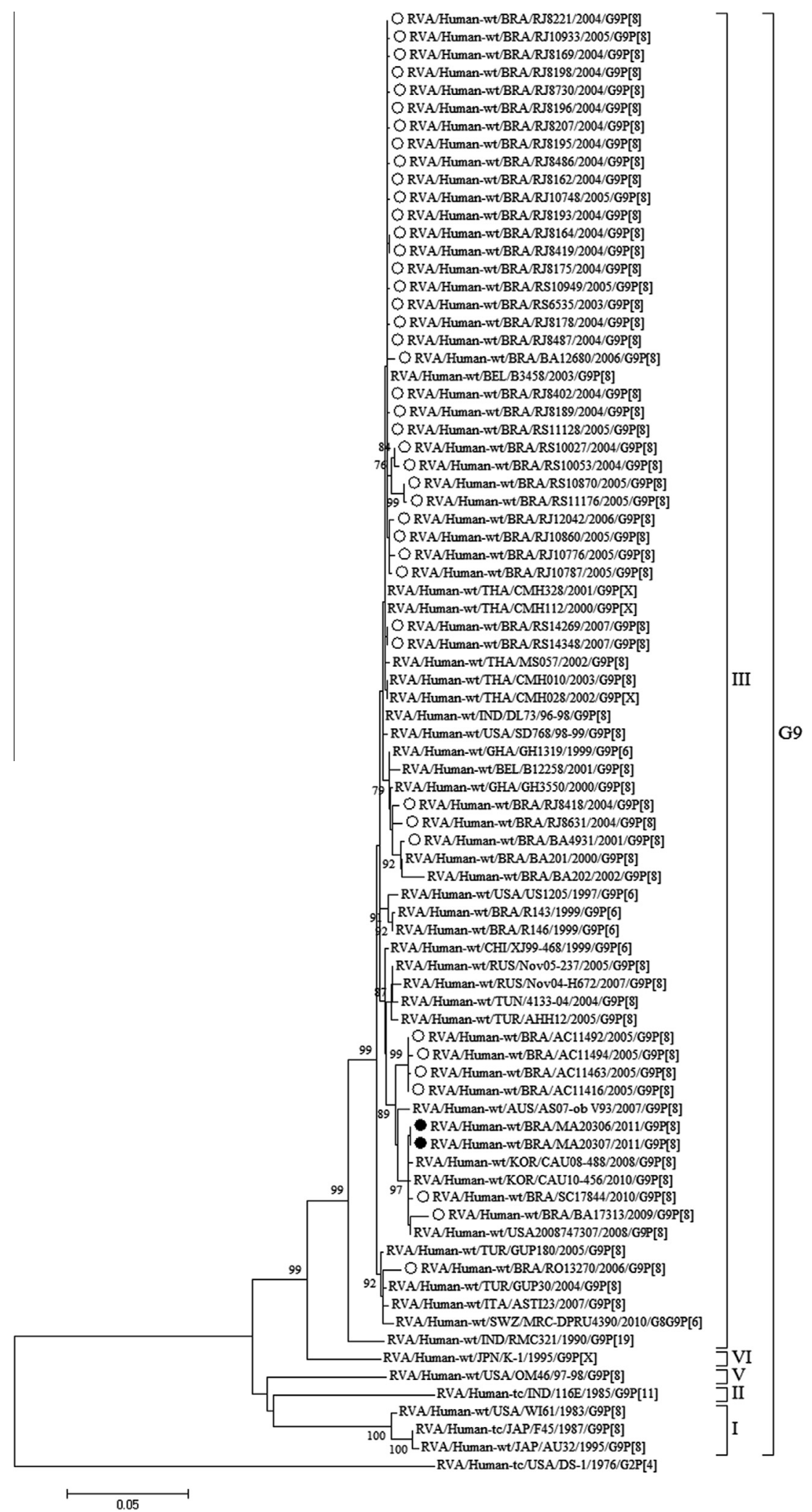

Fig. 4. Phylogenetic analysis based on the VP7 gene nucleotide sequences of Brazilian G9P[8] strains, and sequences from the Genbank database. Brazilian strains obtained from vaccinated and non-vaccinated children are marked with a filled and an empty circle, respectively. Genotype and lineages appeared at the right of the figure. Numbers at the nodes indicate bootstrap values; only values above 70\% are shown. The scale bar at the bottom represents 0.05 substitutions per nucleotide position (nt.subst./site).

(Cortese et al., 2013; Payne et al., 2013), reaching 83\% in Spain (Castilla et al., 2012), 90\% in Belgium (Braeckman et al., 2012), and $75.8 \%$ in Brazil (Justino et al., 2011). Additionally, integrated analyses including all phase II and III trials estimated that RV1 effi- cacy was $90.19 \%$ for G3P[8] strains and $83.76 \%$ for G9P[8] strains (De Vos et al., 2009). Phase III trials in Latin America found that vaccine efficacy reached $80.5 \%$ against pooled non-G1P[8] strains (Linhares et al., 2008; O'Ryan and Linhares, 2009). Since RVA can 
Table 2

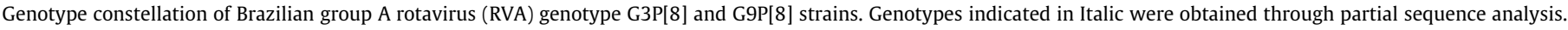

\begin{tabular}{|c|c|c|c|c|c|c|c|c|c|c|c|c|}
\hline \multirow[t]{2}{*}{ Brazilian Strain } & \multirow[t]{2}{*}{ RV1 status } & \multicolumn{11}{|c|}{ Genotypes } \\
\hline & & VP7 & VP4 & VP6 & VP1 & VP2 & VP3 & NSP1 & NSP2 & NSP3 & NSP4 & NSP5 \\
\hline RVA/Human-wt/BRA/ba4931-01/2001/G9P[8] & NVac & G9 & $P[8]$ & I1 & $R 1$ & C1 & M1 & A1 & N1 & T1 & E1 & $\mathrm{H} 1$ \\
\hline RVA/Human-wt/BRA/rs6535-03/2003/G9P[8] & NVac & G9 & $P[8]$ & - & R1 & C1 & - & A1 & N1 & T1 & E1 & $\mathrm{H} 1$ \\
\hline RVA/Human-wt/BRA/RJ8224/2004/G9P[8] & NVac & G9* & $\mathrm{P}[8]$ & I1 & $R 1$ & - & - & $\mathrm{A} 1^{*}$ & N1 & $\mathrm{T} 1^{*}$ & E1 & $\mathrm{H} 1^{*}$ \\
\hline RVA/Human-wt/BRA/RJ10650/2005/G9P[8] & NVac & G9 & $P[8]$ & I1 & - & C1 & - & A1 & N1 & $\mathrm{T} 1$ & E1 & $\mathrm{H} 1$ \\
\hline RVA/Human-wt/BRA/RJ10748/2005/G9P[8] & NVac & G9 & $P[8]$ & I1 & $R 1$ & C1 & M1 & A1 & N1 & $T 1$ & E1 & H1 \\
\hline RVA/Human-wt/BRA/AC11824/2006/G9P[8] & NVac & G9* & $\mathrm{P}[8]$ & $I 1$ & $R 1$ & $C 1$ & - & $\mathrm{A} 1^{*}$ & N1 & $\mathrm{T} 1^{*}$ & E1 & $\mathrm{H} 1^{*}$ \\
\hline RVA/Human-wt/BRA/MA20306/2011/G9P[8] & Vac & G9 & $P[8]$ & I1 & - & $\mathrm{C} 1$ & M1 & A1 & N1 & T1 & E1 & $\mathrm{H} 1$ \\
\hline RVA/Human-wt/BRA/RJ10911/2005/G3P[8] & NVac & G3 & $P[8]$ & $\mathrm{I} 1$ & $R 1$ & C1 & - & A1 & N1 & T1 & E1 & $\mathrm{H} 1$ \\
\hline RVA/Human-wt/BRA/RS16823/2009/G3P[8] & Vac & G3 & $P[8]$ & - & $R 1$ & C1 & - & A1 & N1 & T1 & E1 & $\mathrm{H} 1$ \\
\hline RVA/Human-wt/BRA/RS20345/2011/G3P[8] & NVac & G3 & $\mathrm{P}[8]$ & $\mathrm{I} 1$ & $R 1$ & C1 & - & $\mathrm{A} 1$ & N1 & T1 & E1 & $\mathrm{H} 1$ \\
\hline RVA/Human-wt/BRA/SE20323/2011/G3P[8] & NVac & G3 & $P[8]$ & I1 & $R 1$ & C1 & M1 & A1 & N1 & $\mathrm{T} 1$ & E1 & $\mathrm{H} 1$ \\
\hline
\end{tabular}

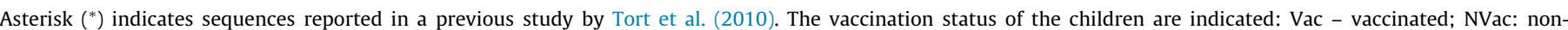
vaccinated; RV1: $\operatorname{Rotarix}^{\circledR} ;(-)$ : without amplification.

be detected in a variable proportion of children vaccinated with RV1, the concept of RV1 vaccine escape strains has to be considered with caution. In addition, RV1 aims to prevent severe DD causing hospitalization and mild infections are expected to occur in the cohort of vaccinated children, as recently reported in Brazilian vaccinated children by Gómez et al. (2013) and Rose et al. (2013). Although few data is available regarding the severity of these infections in vaccinated children, these cases reflect the need for health services and etiologic investigation.

In this study, the rates of RVA detection in the pre- and postvaccination periods were compared. Frequency of RVA infection in DD cases was substantially higher before 2006, prior to RV1 introduction, including in the subgroup of children aged 448 months. In the post-vaccination period, the comparison of RVA detection rates in vaccinated and unvaccinated children showed that children who failed to receive RV1 were more frequently infected with RVA. Nevertheless, the rate of G3 and G9 detections among RVA-positive children was similar in vaccinated and unvaccinated children. Therefore, G3P[8] and G9P[8] infections have been diagnosed in a small proportion of vaccinated children. In Brazil, a regional increase in circulation of RVA genotype G3 was observed in 2005 (prior to universal vaccination), accounting for $30 \%$ of hospitalized children in a public hospital in the city of Rio de Janeiro (Carvalho-Costa et al., 2009). In addition, a geographically restricted increase in detection rate of G3 strains was demonstrated after the introduction of the RV1, in the Southern region of Brazil in 2009 (Carvalho-Costa et al., 2011). RVA genotype G9 emerged in Brazil following a global trend in the 1990s, being detected in near 30\% of RVA-positive samples from 1996 to 2005 (Leite et al., 2008). Furthermore, G9 was detected in the vast majority of RVA-positive patients studied in a large DD outbreak in the State of Acre in 2005 (Siqueira et al., 2010). Frequency of G9 detection decreased substantially following universal vaccination with RV1 in Brazil. It has been demonstrated that RV1 is highly effective against G9 RVA strains (Linhares et al., 2012).

VP8* phylogenetic analysis performed in the current study revealed that G3P[8] strains circulating in Brazil during the study period possessed different alleles of VP8*. For G9P[8] strains different alleles circulating among Brazilian population were also observed. (Fig. 2). Whereas the P[8] of G9 and G3 strains detected between 2001 and 2007 (including one G9P[8] strain detected in 2009) showed close phylogenetic relationship (except for G9P[8] strains detected in Acre in 2005), G9P[8] strains detected between 2010 and 2011 and G3P[8] strains detected between 2009 and 2011, clustered in two separate clusters. As observed for VP8*, different alleles of G3 and G9 VP7 encoding gene circulates among Brazilian population in the period study (Figs. 2 and 4). Regarding strains from vaccinated children, except for strain RVA/Human-wt/
BRA/SC18448/2010/G3P[8] that clustered in a separate branch and was $100 \%$ identical to G3P[8] Thai strains detected during the same year, all clustered together with strains from non-vaccinated children.

G9P[8] strains detected in Acre state in 2005 grouped in a separate cluster for both analyzed genes (Figs. 3 and 4). These strains belongs to an outbreak occurred in Acre in 2005 that caused 12,145 hospitalizations prior to RV1 introduction in Brazil (Siqueira et al., 2010; Tort et al., 2010). Interestingly, all G9P[8] Brazilian strains detected after 2009 showed close phylogenetic relationship with these strains for the VP7 gene (Fig. 4).

Despite the potential emergence of new variants of VP4 and VP7 proteins, able to evade the immune response caused by the vaccine, results obtained in the current study showed no differences inside previous described antigenic epitopes of these two proteins, among Brazilian strains detected before and after vaccine introduction, as well as among Brazilian vaccinated and non-vaccinated strains (Supplementary material Fig. 1). In this study the analysis of complete/partial 11 gene segments of Brazilian G3P[8] and G9P[8] strains revealed a complete Wa-like genotype constellation (Table 2). Wa-like genome constellation in combination with P[8] and different G-genotypes has been the most common human RVA genotype constellation observed worldwide during three decades (Matthijnssens \& Van Ranst, 2012). Furthermore, a correlation has been proposed about the fact that G9P[8] RVA strains circulation increased in human populations during the last two decades, and have also been shown to possess a Wa-like genotype constellation (Matthijnssens et al., 2008; Matthijnssens \& Van Ranst, 2012). It is possible that the acquisition of this genotype constellation might have resulted in their worldwide successful spread among humans (Matthijnssens et al., 2008). In addition, a previous study based on complete genome analysis of fifty-one G3P[8] RVA strains detected between 1974 and 1991 revealed a complete Walike genomic constellation for all strains analyzed (McDonald et al., 2009a,b). Other studies has also correlate G3P[8] strains with a Wa-like genomic background (Matthijnssens et al., 2008; Theamboonlers et al., 2013). As well as G9P[8] strains, G3P[8] strains has been one of the most prevalent genotype combination worldwide, and in Brazil these two genotypes have co-circulate with other RVA strains, including DS-1-like strains (Leite et al., 2008; Carvalho-Costa et al., 2009, 2011; Gómez et al., 2011). However, no inter-geno group reassortments with such DS-1-like strains were observed among analyzed G3 and G9 strains. This might be related to the fact that RVA must balance the advantages of gene reassortments with the disadvantages of unlinking preferred genes/proteins combinations (McDonald et al., 2009a,b).

It is known that VP4 and VP7 antigenic properties play an important role by stimulating the production of neutralizing 
antibodies and represent key factors influencing RVA vaccines performance (Hoshino and Kapikian, 2000). However, other factors such as high titers of RVA-specific antibodies in breast milk and levels of RVA-specific IgA antibodies in the gut lumen have been described as possibly interfering with the efficacy of orally administered vaccines (Patel et al., 2013; Moon et al., 2013; Santos et al., 2013). These factors can also influence vaccine effectiveness and, consequently, the occurrence of RVA infections in (apparently) fully vaccinated children. Additionally, the performance of RVA vaccines in developing countries may be influenced by more complex enteropathogenic profiles, where DD are frequently associated to malnutrition and bacterial and parasitic gut, in poor sanitation backgrounds.

\section{Conclusions}

Genotypes G3 and G9 represents, together 15.5\% of the total RVA infections, being $18 \%$ and $12.3 \%$ in the pre- and post-vaccination periods, respectively, detected in similar proportions among vaccinated and unvaccinated children. P[8] lineage III was observed in all G3 and G9 infections, throughout the pre- and post-vaccination periods, whereas RV1 possesses P[8]-I lineage. Different alleles of VP8* and VP7 encoding genes circulated among Brazilian population during the study period, however this genetic variability was not reflected at amino acid level; no differences were observed in the antigenic composition of G3P[8] and G9P[8] strains for VP8* and VP7 proteins, independently of the vaccination status, geographic area and period. Finally, G3P[8] and G9P[8] Brazilian strains analyzed in the current study hold a Wa-like genetic background. Altogether, results obtained in the current study suggests that changes in the genetic diversity of G3P[8] and G9P[8] from 2001 to 2011 seems not be related to RV1 introduction in Brazil.

\section{Acknowledgments}

This research was supported by funds from the Oswaldo Cruz Institute (IOC - Fiocruz); National Council for Scientific and Technological Development (CNPq); Program of Excellence in Research (PROEP - IOC/Fiocruz/CNPq); the project PAPES VI/Fiocruz - CNPq; Brazilian Federal Agency for Support and Evaluation of Graduate Education (CAPES) - project CAPES-MERCOSUL PCPP 023/2011, the General Coordination of Public Health Laboratories - Secretary of Health Surveillance (CGLAB/SVS/M of H), and Carlos Chagas Filho Foundation for Research Support of Rio de Janeiro State (FAPERJ). The authors would like to thank the Secretary of Public Health of the different Brazilian states involved in the present study. Mariela Martínez Gómez has a Post-Doctoral position at IOC/Fiocruz, supported by a PDJ scholarship from the CNPq.

\section{Appendix A. Supplementary data}

Supplementary data associated with this article can be found, in the online version, at http://dx.doi.org/10.1016/j.meegid.2014. 05.016.

\section{References}

Bányai, K., László, B., Duque, J., Steele, A.D., Nelson, E.A., Gentsch, J.R., Parashar, U.D., 2012. Systematic review of regional and temporal trends in global rotavirus strain diversity in the pre rotavirus vaccine era: insights for understanding the impact of rotavirus vaccination programs. Vaccine 30, A122-A130.

Black, R.E., Cousens, S., Johnson, H.L., Lawn, J.E., Rudan, I., Bassani, D.G., Jha, P., Campbell, H., Walker, C.F., Cibulskis, R., Eisele, T., Liu, L., Mathers, C.Child Health Epidemiology Reference Group of WHO and UNICEF, 2010. Global, regional, and national causes of child mortality in 2008: a systematic analysis. Lancet 375, 1969-1987.
Boom, R., Sol, C.J., Salimans, M.M., Jansen, C.L., Wertheim-van Dillen, P.M., van der Noordaa, J., 1990. Rapid and simple method for purification of nucleic acids. J. Clin. Microbiol. 28, 495-503.

Braeckman, T., Van Herck, K., Meyer, N., Pirçon, J.Y., Soriano-Gabarró, M., Heylen, E. Zeller, M., Azou, M., Capiau, H., De Koster, J., Maernoudt, A.S., Raes, M. Verdonck, L., Verghote, M., Vergison, A., Matthijnssens, J., Van Ranst, M., Van Damme, P.RotaBel Study Group, 2012. Effectiveness of rotavirus vaccination in prevention of hospital admissions for rotavirus gastroenteritis among young children in Belgium: case-control study. BMJ 345, e4752.

Castilla, J., Beristain, X., Martínez-Artola, V., Navascués, A., García Cenoz, M., Alvarez N., Polo, I., Mazón, A., Gil-Setas, A., Barricarte, A., 2012. Effectiveness of rotavirus vaccines in preventing cases and hospitalizations due to rotavirus gastroenteritis in Navarre, Spain. Vaccine 30, 539-543.

Carvalho-Costa, F.A., Volotão, E. de M., de Assis, R.M., Fialho, A.M., de Andrade Jda, S. Rocha, L.N., Tort, L.F., da Silva, M.F., Gómez, M.M., de Souza, P.M., Leite, J.P. 2011. Laboratory-based rotavirus surveillance during the introduction of a vaccination program, Brazil, 2005-2009. Pediatr. Infect. Dis. J. 30, S35-S41.

Carvalho-Costa, F.A., Araújo, I.T., Santos de Assis, R.M., Fialho, A.M., de Assis Martins, C.M., Bóia, M.N., Leite, J.P., 2009. Rotavirus genotype distribution after vaccine introduction, Rio de Janeiro, Brazil. Emerg. Infect. Dis. 15, 95-97.

Carvalho-Costa, F.A., Assis, R.M., Fialho, A.M., Bóia, M.N., Alves, D.P.D., Martins, C.M.M.A., Leite, J.P.G., 2006. Detection and molecular characterization of group A rotavirus from hospitalized children in Rio de Janeiro, Brazil, 2004. Mem. Inst. Oswaldo Cruz 101, 291-294.

Cortese, M.M., Immergluck, L.C., Held, M., Jain, S., Chan, T., Grizas, A.P., Khizer, S. Barrett, C., Quaye, O., Mijatovic-Rustempasic, S., Gautam, R., Bowen, M.D. Moore, J., Tate, J.E., Parashar, U.D., Vázquez, M., 2013. Effectiveness of monovalent and pentavalent rotavirus vaccine. Pediatrics 132, 25-33.

da Silva, M.F., Tort, L.F., Gómez, M.M., Assis, R.M., de Mendonça, M.C., Volotão, E.M. Leite, J.P., 2011. Phylogenetic analysis of VP1, VP2, and VP3 gene segments of genotype G5 group A rotavirus strains circulating in Brazil between 1986 and 2005. Virus Res. 160 (1-2), 381-388.

De Grazia, S., Giammanco, G.M., Potgieter, C.A., Matthijnssens, J., Banyai, K., Platia, M.A., Colomba, C., Martella, V., 2010. Unusual assortment of segments in 2 rare human rotavirus genomes. Emerg. Infect. Dis. 16 (5), 859-862.

De Vos, B., Han, H.H., Bouckenooghe, A., Debrus, S., Gillard, P., Ward, R., Cheuvart, B. 2009. Live attenuated human rotavirus vaccine, RIX4414, provides clinical protection in infants against rotavirus strains with and without shared $G$ and $P$ genotypes: integrated analysis of randomized controlled trials. Pediatr. Infect. Dis. J. 28, 261-266.

Endara, P., Trueba, G., Solberg, O.D., Bates, S.J., Ponce, K., Cevallos, W., Matthijnssens J., Eisenberg, J.N., 2007. Symptomatic and subclinical infection with rotavirus P[8]G9, rural Ecuador. Emerg. Infect. Dis. 13, 574-580.

Esona, M.D., Mijatovic-Rustempasic, S., Foytich, K., Roy, S., Banyai, K., Armah, G.E. Steele, A.D., Volotão, E.M., Gomez, M.M., Silva, M.F., Gautam, R., Quaye, O., Tam, K.I., Forbi, J.C., Seheri, M., Page, N., Nyangao, J., Ndze, V.N., Aminu, M., Bowen, M.D., Gentsch, J.R., 2013. Human G9P[8] rotavirus strains circulating in Cameroon, 1999-2000: genetic relationships with other G9 strains and detection of a new G9 subtype. Infect. Genet. Evol. 18, 315-324.

Estes, M.K., Greenberg, H.B., 2013. Rotaviruses. In: Knipe, D.M., Howley, P.M. (Eds.) Fields Virology. Lippincott Williams and Wilkins, Philadelphia, pp. 1347-1401

Gentsch, J.R., Laird, A.R., Bielfelt, B., Griffin, D.D., Banyai, K., Ramachandran, M., Jain, V., Cunliffe, N.A., Nakagomi, O., Kirkwood, C.D., Fischer, T.K., Parashar, U.D., Bresee, J.S., Jiang, B., Glass, R.I., 2005. Serotype diversity and reassortment between human and animal rotavirus strains: implications for rotavirus vaccine programs. J. Infect. Dis. 192, S146-S159.

Gómez, M.M., de Mendonça, M.C., Volotão, E.M., Tort, L.F., da Silva, M.F., Cristina, J. Leite, J.P., 2011. Rotavirus A genotype P[4]G2: genetic diversity and reassortment events among strains circulating in Brazil between 2005 and 2009. J. Med. Virol. 83 (6), 1093-1106.

Gómez, M.M., da Silva, M.F., Zeller, M., Heylen, E., Matthijnssens, J., Ichihara, M.Y. Rose, T.L., de Mello Volotão, E., Leite, J.P., 2013. Phylogenetic analysis of G1P[6] group A rotavirus strains detected in Northeast Brazilian children fully vaccinated with Rotarix TM. Infect. Genet. Evol. 19, 395-402.

Guo, D., Liu, J., Lu, Y., Sun, Y., Yuan, D., Jiang, Q., Lin, H., Li, C., Si, C., Qu, L., 2012. Ful genomic analysis of rabbit rotavirus G3P[14] strain N5 in China: identification of a novel VP6 genotype. Infect. Genet. Evol. 12, 1567-1576.

Hall, T.A., 1999. BioEdit: a user-friendly biological sequence alignment editor and analysis program for Windows 95/98/NT. Nucleic Acids Symp. 41, 95-98.

He, B., Yang, F., Yang, W., Zhang, Y., Feng, Y., Zhou, J., Xie, J., Feng, Y., Bao, X., Guo, H., Li, Y., Xia, L., Li, N., Matthijnssens, J., Zhang. H., Tu, C., 2013. Characterization of a novel G3P[3] rotavirus isolated from a lesser horseshoe bat: a distant relative of feline/canine rotaviruses. J. Virol. 87, 12357-12366.

Hoshino, Y., Kapikian, A.Z., 2000. Rotavirus serotypes: classification and importance in epidemiology, immunity, and vaccine development. J. Health Popul. Nutr. 18, 514.

Hull, J.J., Teel, E.N., Kerin, T.K., Freeman, M.M., Esona, M.D., Gentsch, J.R., Cortese, M.M., Parashar, U.D., Glass, R.I., Bowen, M.D., 2011. System NRSS: United States rotavirus strain surveillance from 2005 to 2008: genotype prevalence before and after vaccine introduction. Pediatr. Infect. Dis. J. 30, S42-S47.

Iturriza-Gómara, M., Dallman, T., Bányai, K., Böttiger, B., Buesa, J., Diedrich, S., Fiore, L., Johansen, K., Korsun, N., Kroneman, A., Lappalainen, M., László, B., Maunula, L., Matthijnssens, J., Midgley, S., Mladenova, Z., Poljsak-Prijatelj, M., Pothier, P. Ruggeri, F.M., Sanchez-Fauquier, A., Schreier, E., Steyer, A., Sidaraviciute, I., Tran, A.N., Usonis, V., Van Ranst, M., de Rougemont, A., Gray, J., 2009. Rotavirus 
surveillance in Europe, 2005-2008: web-enabled reporting and real-time analysis of genotyping and epidemiological data. J. Infect. Dis. 200, S215-S221.

Justino, M.C., Linhares, A.C., Lanzieri, T.M., Miranda, Y., Mascarenhas, J.D., Abreu, E., Guerra, S.F., Oliveira, A.S., da Silva, V.B., Sanchez, N., Meyer, N., Shafi, F., OrtegaBarria, E., Soriano-Gabarró, M., Colindres, R.E., 2011. Effectiveness of the monovalent G1P[8] human rotavirus vaccine against hospitalization for severe G2P[4] rotavirus gastroenteritis in Belém, Brazil. Pediatr. Infect. Dis. J. 30, 396-401.

Kirkwood, C.D., Boniface, K., Barnes, G.L., Bishop, R.F., 2011. Distribution of rotavirus genotypes after introduction of rotavirus vaccines, Rotarix ${ }^{\circledR}$ and RotaTeq ${ }^{\circledR}$, into the National Immunization Program of Australia. Pediatr. Infect. Dis. J. 30, S48 S53.

Kotloff, K.L., Nataro, J.P., Blackwelder, W.C., Nasrin, D., Farag, T.H., Panchalingam, S., Wu, Y., Sow, S.O., Sur, D., Breiman, R.F., Faruque, A.S., Zaidi, A.K., Saha, D., Alonso P.L., Tamboura, B., Sanogo, D., Onwuchekwa, U., Manna, B., Ramamurthy, T., Kanungo, S., Ochieng, J.B., Omore, R., Oundo, J.O., Hossain, A., Das, S.K., Ahmed S., Qureshi, S., Quadri, F., Adegbola, R.A., Antonio, M., Hossain, M.J., Akinsola, A., Mandomando, I., Nhampossa, T., Acácio, S., Biswas, K., O’Reilly, C.E., Mintz, E.D. Berkeley, L.Y., Muhsen, K., Sommerfelt, H., Robins-Browne, R.M., Levine, M.M. 2013. Burden and aetiology of diarrhoeal disease in infants and young children in developing countries (the Global Enteric Multicenter Study, GEMS): a prospective, case-control study. Lancet 382, 209-222.

Laird, A.R., Gentsch, J.R., Nakagomi, T., Nakagomi, O., Glass, R.I., 2003. Characterization of serotype G9 rotavirus strains isolated in the United States and India from 1993 to 2001. J. Clin. Microbiol. 41, 3100-3101.

Leite, J.P., Carvalho-Costa, F.A., Linhares, A.C., 2008. Group A rotavirus genotypes and the ongoing Brazilian experience: a review. Mem. Inst. Oswaldo Cruz 103 $745-753$.

Leite, J.P.G., Alfieri, A.A., Woods, P.A., Glass, R.I., Gentsch, J.R., 1996. Rotavirus G and P types circulating in Brazil: characterization by RT-PCR, probe hybridization, and sequence analysis. Arch. Virol. 141, 2365-2374.

Linhares, A.C., Justino, M.C., 2014. Rotavirus vaccination in Brazil: effectiveness and health impact seven years post-introduction. Expert Rev. Vaccines 13, 43-57.

Linhares, A.C., Stupka, J.A., Ciapponi, A., Bardach, A.E., Glujovsky, D., Aruj, P.K., Mazzoni, A., Rodriguez, J.A., Rearte, A., Lanzieri, T.M., Ortega-Barria, E. Colindres, R., 2011. Burden and typing of rotavirus group A in Latin America and the Caribbean: systematic review and meta-analysis. Rev. Med. Virol. 21, 89-109.

Linhares, A.C., Velázquez, F.R., Pérez-Schael, I., Sáez-Llorens, X., Abate, H., Espinoza, F., López, P., Macías-Parra, M., Ortega-Barría, E., Rivera-Medina, D.M., Rivera, L., Pavía-Ruz, N., Nuñez, E., Damaso, S., Ruiz-Palacios, G.M., De Vos, B., O’Ryan, M. Gillard, P., Bouckenooghe, A.Human Rotavirus Vaccine Study Group, 2008. Efficacy and safety of an oral live attenuated human rotavirus vaccine against rotavirus gastroenteritis during the first 2 years of life in Latin American infants: a randomised, double-blind, placebo-controlled phase III study. Lancet 371, 1181-1189.

Malik, Y.S., Sharma, K., Vaid, N., Chakravarti, S., Chandrashekar, K.M., Basera, S.S. Singh, R., Minakshi Prasad, G., Gulati, B.R., Bhilegaonkar, K.N., Pandey, A.B. 2012. Frequency of group $A$ rotavirus with mixed $G$ and $P$ genotypes in bovines: predominance of G3 genotype and its emergence in combination with G8/G10 types. J. Vet. Sci. 13, 271-278.

Matthijnssens, J., Ciarlet, M., Heiman, E., Arijs, I., Delbeke, T., McDonald, S.M. Palombo, E.A., Iturriza-Gómara, M., Maes, P., Patton, J.T., Rahman, M., Van Ranst, M., 2008. Full genome-based classification of rotaviruses reveals a common origin between human Wa-Like and porcine rotavirus strains and human DS-1like and bovine rotavirus strains. J. Virol. 82, 3204-3219.

Matthijnssens, J., Heylen, E., Zeller, M., Rahman, M., Lemey, P., Van Ranst, M., 2010a. Phylodynamic analyses of rotavirus genotypes G9 and G12 underscore thei potential for swift global spread. Mol. Biol. Evol. 27, 2431-2436.

Matthijnssens, J., Taraporewala, Z.F., Yang, H., Rao, S., Yuan, L., Cao, D., Hoshino, Y. Mertens, P.P., Carner, G.R., McNeal, M., Sestak, K., Van Ranst, M., Patton, J.T., 2010b. Simian rotaviruses possess divergent gene constellations that originated from interspecies transmission and reassortment. J. Virol. 84 (4), 2013-2026.

Matthijnssens, J., Van Ranst, M., 2012. Genotype constellation and evolution of group A rotaviruses infecting humans. Curr. Opin. Virol. 2 (4), 426-433.

McDonald, S.M., Matthijnssens, J., McAllen, J.K., Hine, E., Overton, L., Wang, S., Lemey, P., Zeller, M., Van Ranst, M., Spiro, D.J., Patton, J.T., 2009a. Evolutionary dynamics of human rotaviruses: balancing reassortment with preferred genome constellations. PLoS Pathog. 5, e1000634.

McDonald, S.M., Aguayo, D., Gonzalez-Nilo, F.D., Patton, J.T., 2009b. Shared and group-specific features of the rotavirus RNA polymerase reveal potential determinants of gene reassortment restriction. J. Virol. 83, 6135-6148.

Mitui, M.T., Chan, P.K.S., Nelson, E.A.S., Leung, T.F., Nishizono, A., Ahmed, K., 2011 Co-dominance of G1 and emerging G3 rotaviruses in Hong Kong: a three-year surveillance in three major hospitals. J. Clin. Virol. 50, 325-333.

Moon, S.S., Tate, J.E., Ray, P., Dennehy, P.H., Archary, D., Coutsoudis, A., Bland, R., Newell, L., Glass, R.I., Parashar, U., Jiang, B., 2013. Differential profiles and inhibitory effect on rotavirus vaccines of nonantibody components in breast milk from mothers in developing and developed countries. Pediatr. Infect. Dis. J. $32,863-870$

Nemoto, M., Tsunemitsu, H., Murase, H., Nambo, Y., Sato, S., Orita, Y., Imagawa, H., Bannai, H., Tsujimura, K., Yamanaka, T., Matsumura, T., Kondo, T., 2012 Antibody response in vaccinated pregnant mares to recent G3BP[12] and G14P[12] equine rotaviruses. Acta Vet. Scand. 54, 63.

Ngo, T.C., Nguyen, B.M., Dang, D.A., Nguyen, H.T., Nguyen, T.T., Tran, V.N., Vu, T.T Ogino, M., Alam, M.M., Nakagomi, T., Nakagomi, O., Yamashiro, T., 2009.
Molecular epidemiology of rotavirus diarrhoea among children in Haiphong, Vietnam: the emergence of G3 rotavirus. Vaccine 27 (Suppl. 5), F75-F80.

Nyaga, M.M., Jere, K.C., Peenze, I., Mlera, L., Van Dijk, A.A., Seheri, M.L., Mphahlele, M.J., 2013. Sequence analysis of the whole genomes of five African human G9 rotavirus strains. Infect. Genet. Evol. 16, 62-77.

Okitsu, S., Khamrin, P., Thongprachum, A., Kongkaew, A., Maneekarn, N., Mizuguchi, M., Hayakawa, S., Ushijima, H., 2013. Whole-genomic analysis of G3P[23], G9P[23] and G3P[13] rotavirus strains isolated from piglets with diarrhea in Thailand, 2006-2008. Infect. Genet. Evol. 18, 74-86.

O'Ryan, M., Linhares, A.C., 2009. Update on Rotarix: an oral human rotavirus vaccine. Expert. Rev. Vaccines 8, 1627-1641.

Page, N., Esona, M., Armah, G., Nyangao, J., Mwenda, J., Sebunya, T., Basu, G., Pyndiah, N., Potgieter, N., Geyer, A., Steele, A.D., 2010. Emergence and characterization of serotype G9 rotavirus strains from Africa. J. Infect. Dis. 202 (Suppl.), S55-S63.

Patel, M., Glass, R.I., Jiang, B., Santosham, M., Lopman, B., Parashar, U., 2013. A systematic review of anti-rotavirus serum IgA antibody titer as a potential correlate of rotavirus vaccine efficacy. J. Infect. Dis. 208, 284-294.

Payne, D.C., Boom, J.A., Staat, M.A., Edwards, K.M., Szilagyi, P.G., Klein, E.J., Selvarangan, R., Azimi, P.H., Harrison, C., Moffatt, M., Johnston, S.H., Sahni, L.C., Baker, C.J., Rench, M.A., Donauer, S., McNeal, M., Chappell, J., Weinberg, G.A., Tasslimi, A., Tate, J.E., Wikswo, M., Curns, A.T., Sulemana, I., MijatovicRustempasic, S., Esona, M.D., Bowen, M.D. Gentsch, J.R. Parashar, U.D., 2013. Effectiveness of pentavalent and monovalent rotavirus vaccines in concurrent use among US children $<5$ years of age, 2009-2011. Clin. Infect. Dis. 57, $13-20$.

Pereira, H.G., Azeredo, R.S., Leite, J.P., Candeias, J.A., Rácz, M.L., Linhares, A.C., Gabbay, Y.B., Trabulsi, J.R., 1983. Electrophoretic study of the genome of human rotaviruses from Rio de Janeiro, São Paulo and Pará, Brazil. J. Hyg. (Lond.) 90, 117-125.

Rahman, M., Matthijnssens, J., Goegebuer, T., De Leener, K., Vanderwegen, L., van der Donck, I., Van Hoovels, L., De Vos, S., Azim, T., Van Ranst, M., 2005. Predominance of rotavirus G9 genotype in children hospitalized for rotavirus gastroenteritis in Belgium during 1999-2003. J. Clin. Virol. 33, 1-6.

Rahman, M., Yang, X.L., Sun, H., Mahzebin, K., Verstappen, N.W., Novo, L., Matthijnssens, J., Van Ranst, M., 2008. Emerging G9 rotavirus strains in the northwest of China. Virus Res. 137, 157-162.

Rose, T.L., Marques da Silva, M.F., Goméz, M.M., Resque, H.R., Ichihara, M.Y., Volotão, E.M., Leite, J.P., 2013. Evidence of vaccine-related reassortment of rotavirus, Brazil, 2008-2010. Emerg. Infect. Dis. 19, 1843-1846.

Sánchez-Fauquier, A., Montero, V., Moreno, S., Solé, M., Colomina, J., IturrizaGomara, M., Revilla, A., Wilhelmi, I., Gray, J.Gegavi/VIGESS-Net Group, 2006. Human rotavirus G9 and G3 as major cause of diarrhea in hospitalized children, Spain. Emerg. Infect. Dis. 12, 1536-1541.

Santos, S.M., Ferreira, T.L., Quintal, V.S., Carbonare, S.B., Tino-De-Franco, M., 2013. Milk from Brazilian women presentes secretory IgA antibodies and neutralizes rotavirus G9P[5]. J. Pediatr. (Rio J.) 89, 510-513.

Siqueira, A.A., Santelli, A.C., Alencar Jr., L.R., Dantas, M.P., Dimech, C.P., Carmo, G.M., Santos, D.A., Alves, R.M., Lucena, M.B., Morais, M., Assis, R.M., Fialho, A., Mascarenhas, J.D., Costa, M., Linhares, A.C., Leite, J.P., Araujo, W.N., Hatch, D.L., 2010. Outbreak of acute gastroenteritis in young children with death due to rotavirus genotype G9 in Rio Branco, Brazilian Amazon region, 2005. Int. J. Infect. Dis. 14, e898-e903.

Tamura, K., Peterson, D., Peterson, N., Stecher, G., Nei, M., Kumar, S., 2011. MEGA5: molecular evolutionary genetics analysis using maximum likelihood, evolutionary distance, and maximum parsimony methods. Mol. Biol. Evol. 28, 2731-2739.

Tate, J.E., Patel, M.M., Cortese, M.M., Lopman, B.A., Gentsch, J.R., Fleming, J., Steele, A.D., Parashar, U.D., 2012. Remaining issues and challenges for rotavirus vaccine in preventing global childhood diarrheal morbidity and mortality. Expert Rev. Vaccines 11, 211-220.

Theamboonlers, A., Maiklang, O., Thongmee, T., Chieochansin, T., Vuthitanachot, V., Poovorawan, Y., 2013. Complete genotype constellation of human rotavirus group A circulating in Thailand, 2008-2011. Infect. Genet. Evol. 1 (21C), 295302.

Thompson, J.D., Higgins, D.G., Gibson, T.J., 1994. CLUSTAL W: improving the sensitivity of progressive multiple sequence alignment through sequence weighting, position-specific gap penalties and weight matrix choice. Nucleic Acids Res. 22, 4673-4680.

Tort, L.F., Volotão, E.de M., de Mendonça, M.C., da Silva, M.F., Siqueira, A.A., Assis, R.M., Moratorio, G., Cristina, J., Leite, J.P., 2010. Phylogenetic analysis of human P[8]G9 rotavirus strains circulating in Brazil reveals the presence of a novel genetic variant. J. Clin. Virol. 47, 345-355.

Trojnar, E., Sachsenröder, J., Twardziok, S., Reetz, J., Otto, P.H., Johne, R., 2013. Identification of an avian group A rotavirus containing a novel VP4 gene with a close relationship to those of mammalian rotaviruses. J. Gen. Virol. 94, $136-142$.

Walker, C.L., Rudan, I., Liu, L., Nair, H., Theodoratou, E., Bhutta, Z.A., O’Brien, K.L., Campbell, H., Black, R.E., 2013. Global burden of childhood pneumonia and diarrhoea. Lancet 38, 1405-1416.

Wazny, K., Zipursky, A., Black, R., Curtis, V., Duggan, C., Guerrant, R., Levine, M., Petri Jr., W.A., Santosham, M., Scharf, R., Sherman, P.M., Simpson, E., Young, M., Bhutta, Z.A., 2013. Setting research priorities to reduce mortality and morbidity of childhood diarrhoeal disease in the next 15 years. PLoS Med. 10, e1001446.

World Health Organization, 2013. Rotavirus vaccines WHO position paper: January 2013 - recommendations. Vaccine 31, 6170-6171. 